\title{
Designing a Website Based Aceh Translation Application Using Rule-Based
}

\author{
Fadhliati * \\ Information Technology Faculty, STMIK Abulyatama \\ Email: fadhliatiskom@gmail.com
}

Received: 23 December 2020; Accepted: 28 March 2021; Published: 13 April 2021

\begin{abstract}
Language is a means of communication between community members in the form of sound symbols produced by human speech tools, language is also a means of self-expression as well as a tool to show self-identity. With the very rapid development of technology, especially in the field of information technology, the problems previously described can be overcome by building a web-based text to Aceh language translator system. Research on the translation system uses three main approaches, namely a rule-based, statistical and example-based approach. The method used consists of 2 (two), namely the system development method with the waterfall method and the rule base method for parsing the dictionary data. Based on the results of the analysis and design of the Aceh language translator application, it can be seen that; The design of an Acehnese translator application can provide convenience in carrying out the process of translating Acehnese into Indonesia and vice versa, and the rule-based method is used to anticipate the limited number of words contained in the database, which are Indonesian words that have similarities in Acehnese made in a certain pattern of rules. The rule-based used in this application is the change rule in the front syllable, back syllable, middle syllable, and their combinations.
\end{abstract}

Index Terms: Design; Translation Application; Aceh Language; Website; Rule-Based.

\section{Introduction}

Language is a means of communication between community members in the form of sound symbols produced by human speech tools $[1,2,3]$, language is also a means of self-expression as well as a tool to show self-identity $[4,5]$. Through language, we can show our point of view, our understanding of something, the origin of our nation and country, our education, even our nature [6]. This language is the medium of communication for exchanging information between residents of the area [7,8]. To help understand the language of a certain country or region, it takes a tool or object which is generally called a dictionary, so that language differences are no longer an obstacle in exchanging information, in this case [9]. The Acehnese language is the language most widely used by the local population as a language in daily conversation, even though Indonesian is the national language but Acehnese language is still predominantly used by the community. There are 9 regional languages in Aceh spoken by the community in several areas but the Acehnese language is better known by the local community [10]. The Aceh language is an ideal communication to use in communicating with local residents, however, most tourists and visitors experience problems in communication. because foreign tourists certainly do not know the language.

With the very rapid development of technology, especially in the field of information technology, the problems previously described can be overcome by building a web-based text to Aceh language translator system. Research on language translation systems has been carried out and the results are tested quite a lot. Research on the translation system uses three main approaches, namely a rule-based, statistical, and example-based approach. The expected benefit from this research is that it is hoped that this web-based Aceh language translator application can be used as a practical learning aid for the Acehnese language and help preserve the regional language of Aceh.

\section{Research Method}

To assist in the preparation of this research, it is necessary to have a clear framework in stages [11]. This framework represents the steps that will be taken in solving the problems that will be discussed [12]. The research framework used is as shown in Figure 1. 


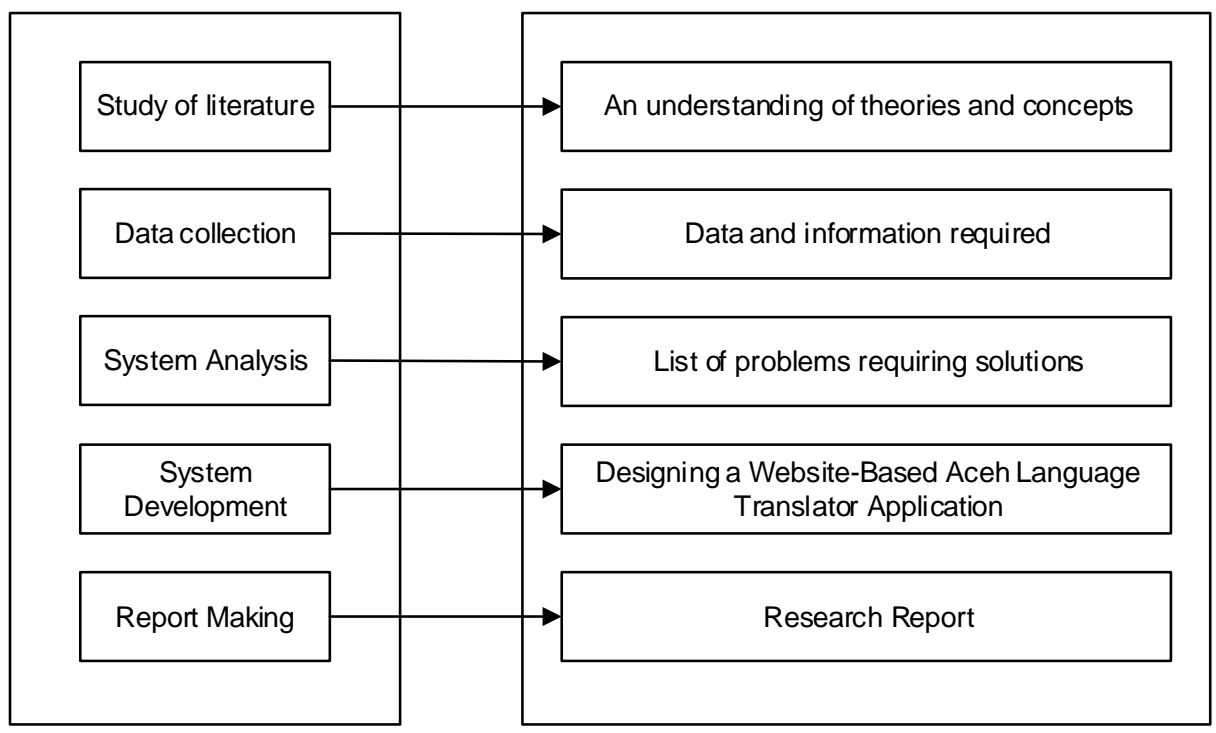

Fig.1. Research Framework

Based on the research framework described above, the discussion of each stage in the research can be described as follows:

1. Literature Study

At this stage, the search for theoretical foundations obtained from various books and the internet is also carried out to complement the vocabulary of concepts and theories, so that they have a good and appropriate foundation and science.

2. Data Collection

At this stage, the process of collecting data by interviewing and observing methods is carried out to make observations and analysis of the translator application process that is currently running in order to obtain the data and information needed by researchers.

3. System Analysis

At this stage, problem identification is carried out in the running system. Thus, it is hoped that researchers can find the obstacles and problems that occur in the translator application process in various applications such as google translate so that researchers can find solutions to these problems.

4. System Development

At this stage, system development is carried out using the waterfall model.

5. Reporting

At this stage, reports are prepared based on research results using primary and secondary data collection techniques so that they become research reports that can provide a complete picture of the system being built.

The system analysis for the Aceh language translator application is as follows:

1. The application is able to translate words from Indonesian to Acehnese and vice versa by directly inputting the word to be translated in the provided text input.

2. This application also has an admin in the form of a web page that is used for the process of adding, editing, and deleting words, and types of words when additions are needed. add, edit, and delete words, and word types if any time it is necessary to add them.

The natural language components in this dictionary application are as follows:

a. Parser, functions to perform syntactic analysis.

b. The knowledge representation system in this application is as follows:

1) Word, contains Indonesian words and their meaning in Acehnese, as well as types of words.

2) Type, contains types of words, such as (nouns, adjectives, verbs, etc.).

c. Translator output, is the output of the translation process. The explanation of each process is as follows:

1) Syntax analysis

Input text is separated by checking each character in the input as many as the number of text characters entered separated by empty characters (spaces), then this process can obtain the types of words inputted.

2) Syntax analysis and sentence rule analysis

Sentence rule analysis is useful for checking whether the word input is in accordance with the word rules contained in the program. If the word input is in accordance with the existing rules, the translated sentence will appear in accordance with the word rules and syntax, but if it does not match, then the translated word will be 
displayed without using the word rules Syntax regulates combining and sorting different types of words such as nouns, words work, adjectives, etc., and placing words in a specific order so as to form the correct word and language

The Linear Sequential Model often called the Waterfall Model, is the oldest and most widely used software engineering paradigm [13]. This model proposes a systematic and partial software development approach starting at the level and progress of the system throughout the analysis, design, code, testing, and maintenance. This model is used as the basis for making translation applications [14].

\section{Analysis}

\section{Design}

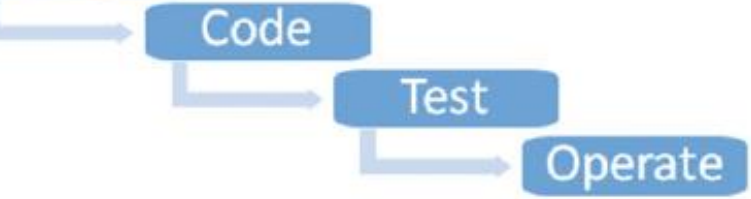

Fig.2. Stages in the Waterfall Model

The design is useful for describing the system data flow in translating Indonesian into Acehnese and from Acehnese into Indonesian. The design is in the form of a flowchart (system flow chart). Flowcharts are designed to make it easier to understand the system to be built. The picture below is a flowchart of the Indonesian-Aceh language dictionary application.

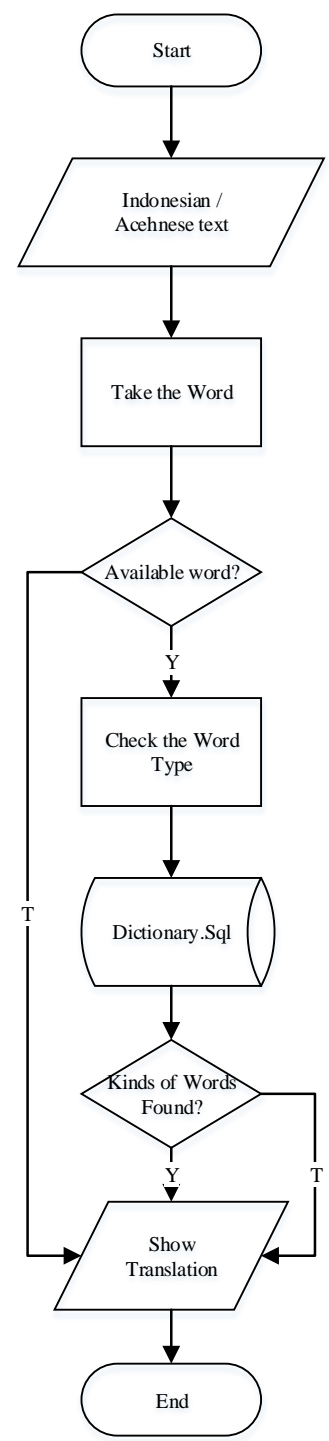

Fig.3. Flowchart of the Proposed Translator Application 
In Figure 3 it can be explained that the application starts with determining the language selection whether you want to translate Indonesian to Aceh or Acehnese to Indonesian. Furthermore, the word that is typed is taken to be checked on the application database and checked for the type of word in the database. If the word is available in the database, the translation results will be displayed in the form of a word on the form and if it is not available then the translation cannot be displayed either in Indonesian or in Acehnese.

\section{Result and Discussion}

The design of this Aceh language translator application aims to provide an overview to identify the components to be designed. The design uses the PHP and MySQL programming languages which the authors design consists of several stages, namely input design, output design, and system implementation. The writer hopes that this design will make it easier for each user, especially the translation section. Implementation is the stage where the system is ready to operate at the actual stage so that it will be known whether the system that has been created is really as planned. In the implementation of this software, it will be explained how this system program works, by providing a view of the system or application being made. The implementation of this application consists of several pages that have their own functions. The pages will appear sequentially according to the order that has been programmed.

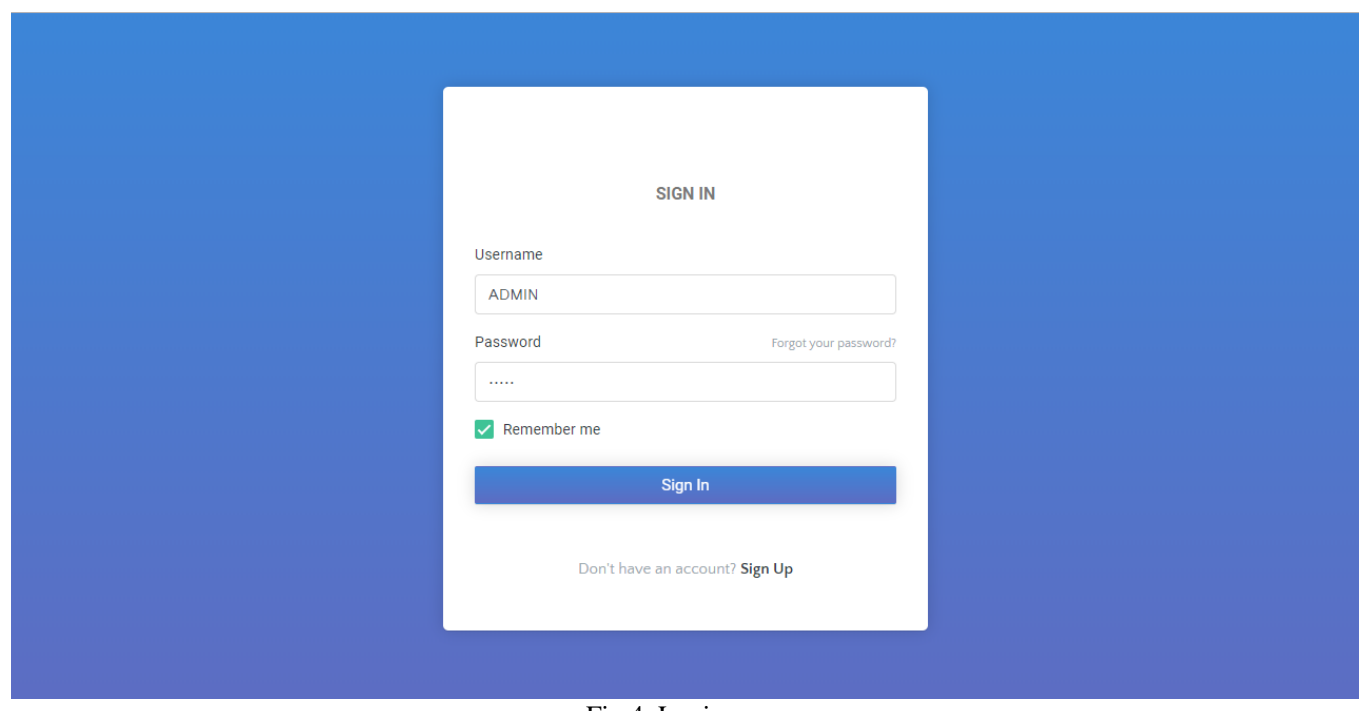

Fig.4. Login page

The login page is a security against who is not entitled to enter the admin page. The login page consists of 2 (two) entries, namely; username and password. If one of them is not correct, it will return to the login form. If successful, it will be redirected to the admin page.

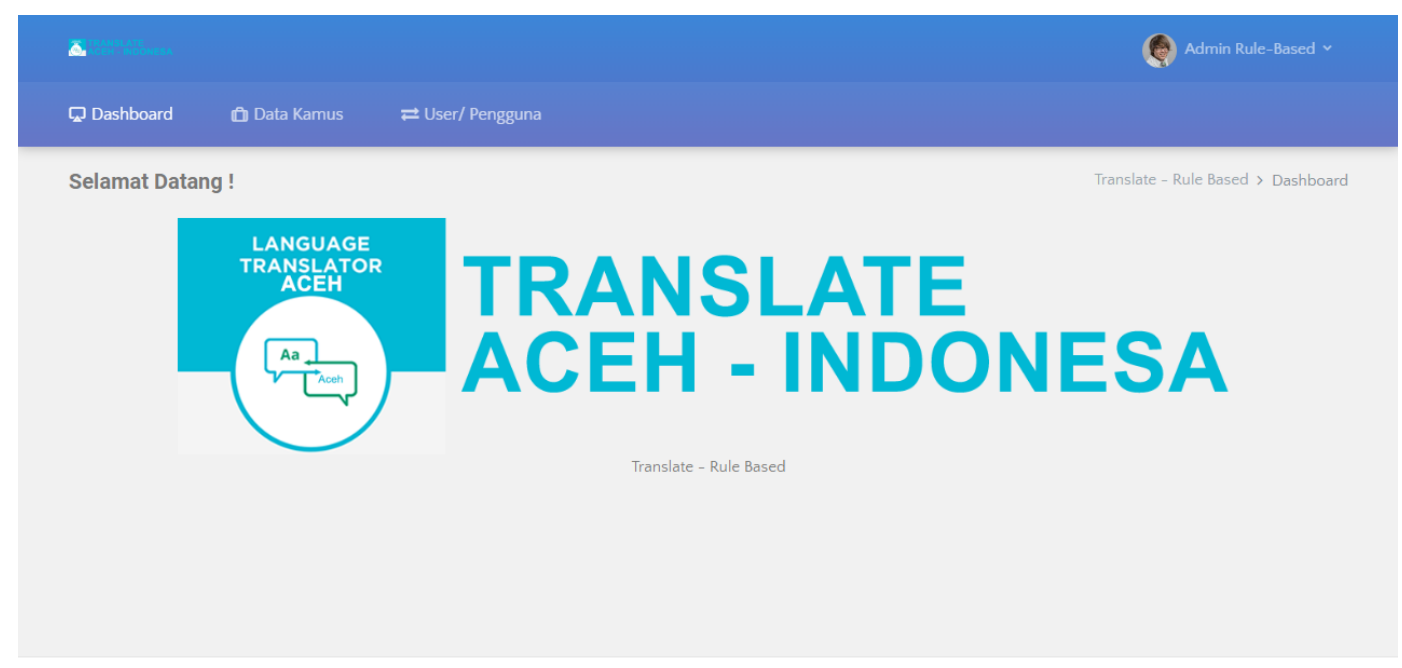

Fig.4. Admin page 
The admin page consists of several menus such as; dashboard, data dictionary, user / user, the data dictionary sub menu consists of aceh language dictionary and Indonesian.

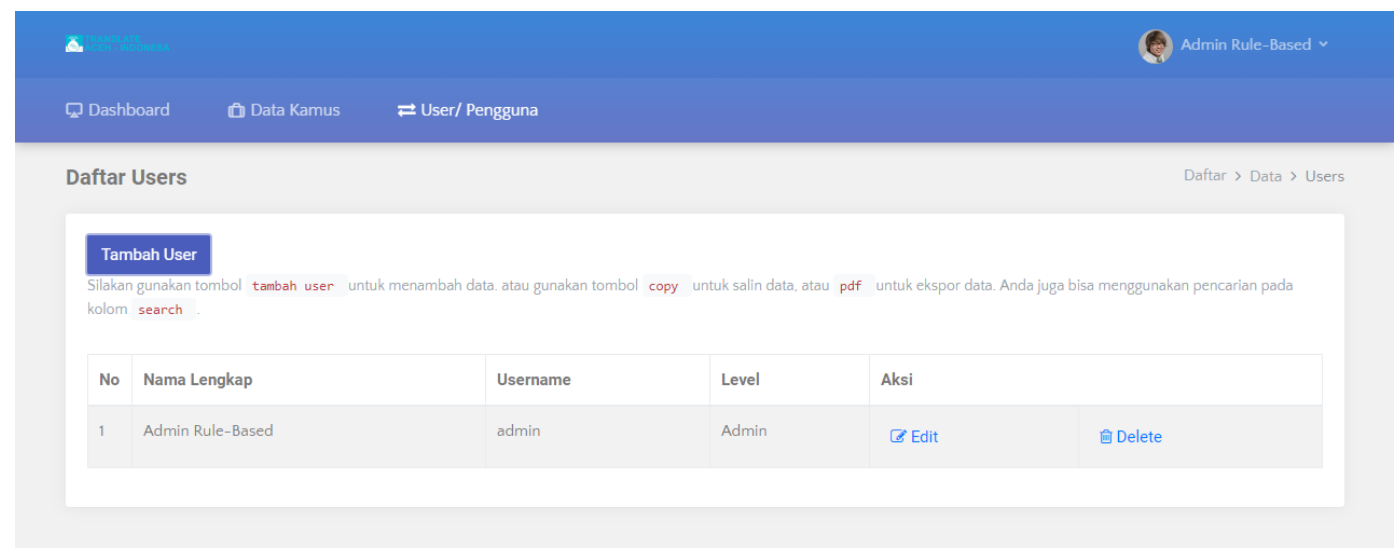

Fig.5. User List Master page

On this page the user will be registered and displayed here. Furthermore, operators and operators can add application user data. For user registration, operators can click the add user button to add data as shown in Figure 6 below .

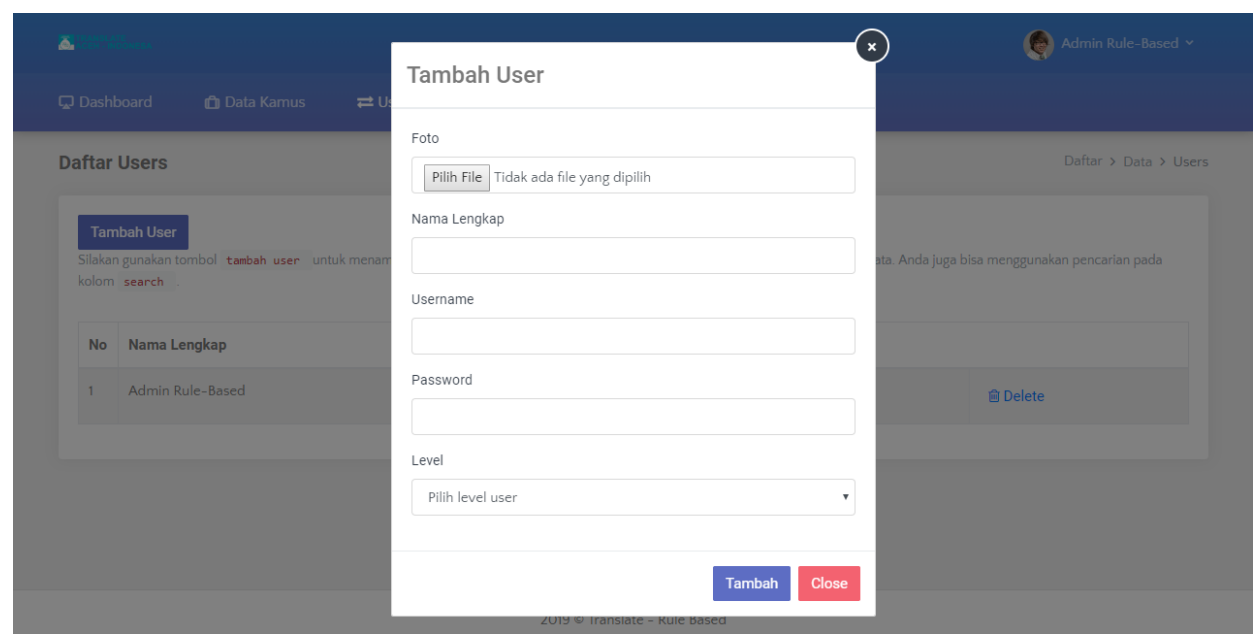

Fig.6. Add User page

The added user form page consists of a user name, username, password, and access level for this application.

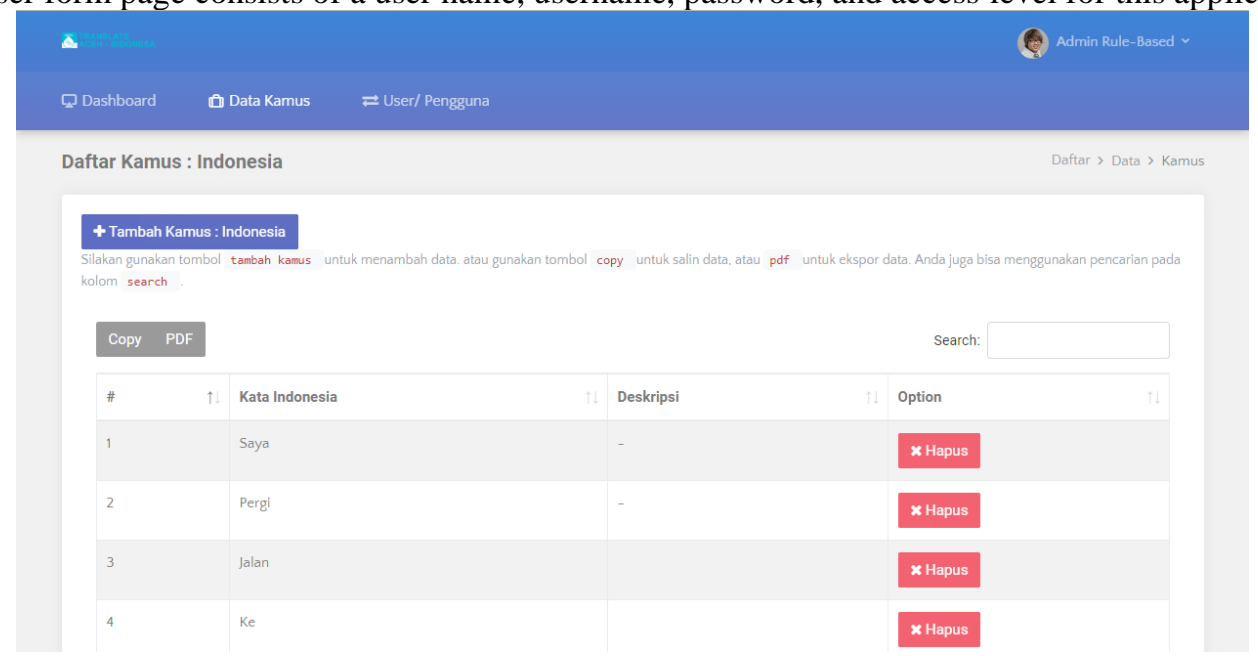

Fig.7. Indonesian Dictionary List page 
On the Indonesian dictionary list page is the result of filling in Indonesian dictionary data, on this page appears when selecting the master data dictionary sub menu. To add data to the Indonesian dictionary, you can click the add dictionary button so that the added dictionary form will be displayed as shown in Figure 8 below.

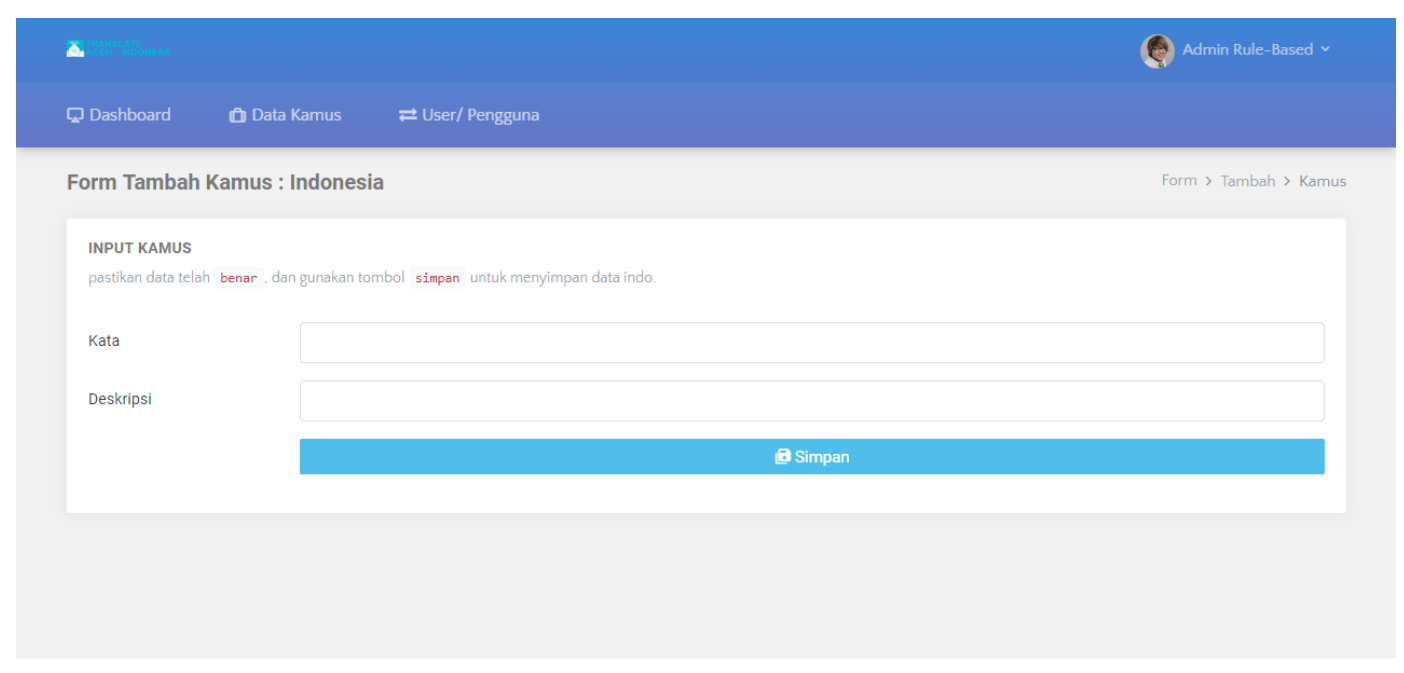

2019 ๑ Translate - Rule Based

Fig.8. Add Indonesian Dictionary page

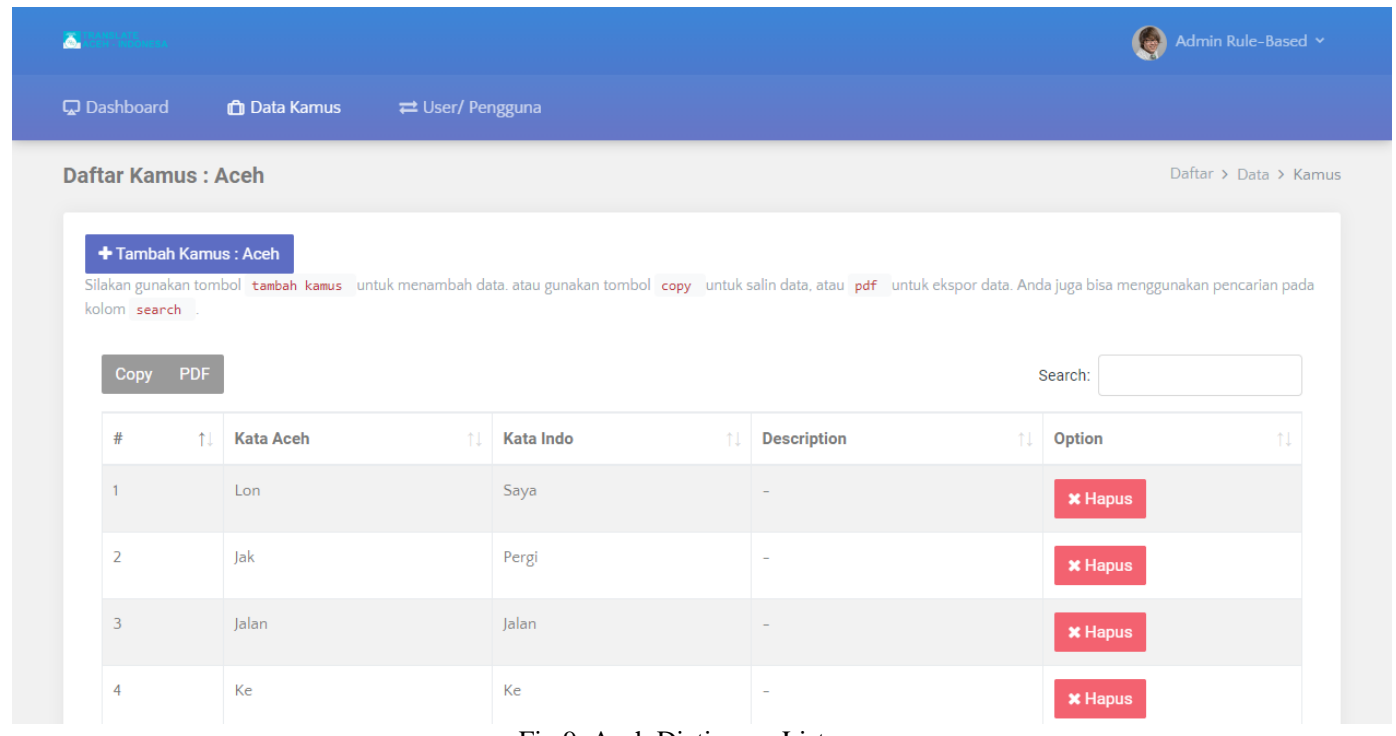

Fig.9. Aceh Dictionary List page

On the list page of the Aceh dictionary is the result of filling in the Aceh dictionary data, on this page appears when selecting the master data dictionary sub menu. To add data to the Aceh language dictionary, you can click the add dictionary button so that the added Aceh dictionary form will be displayed as shown in Figure 10 below. 


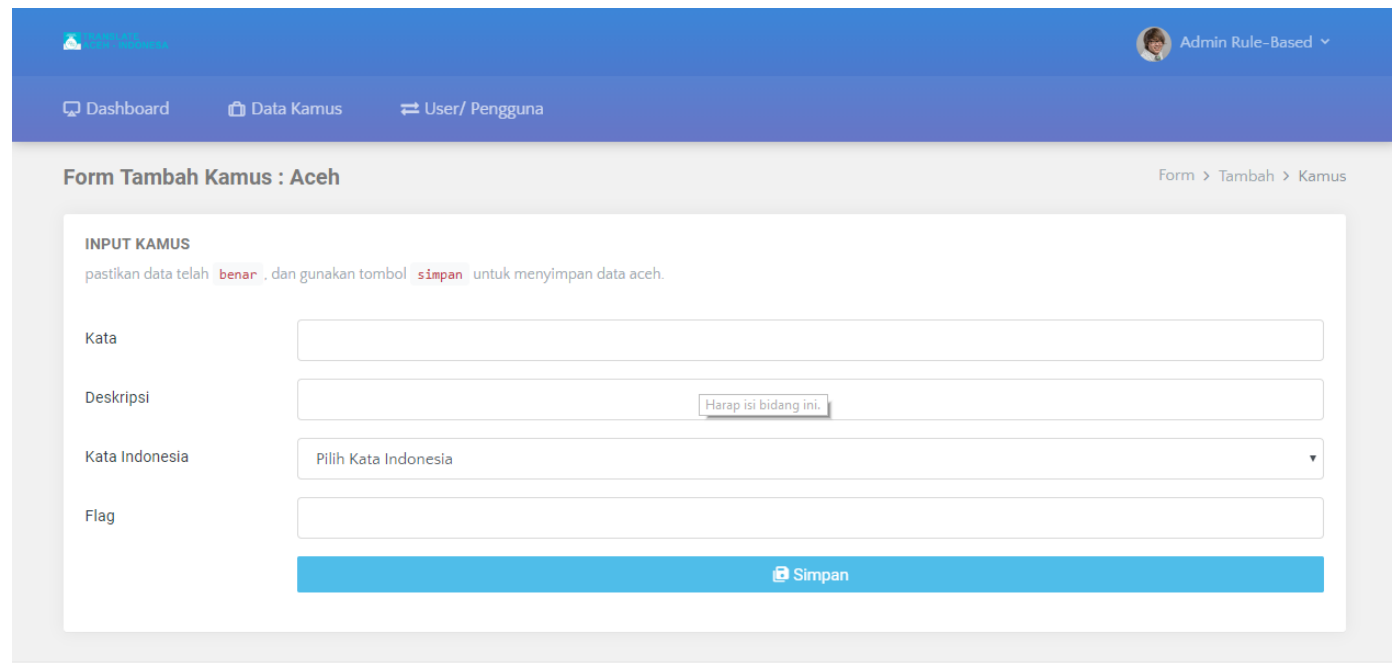

20190 Translate - Rule Based

Fig.10. Add Program page

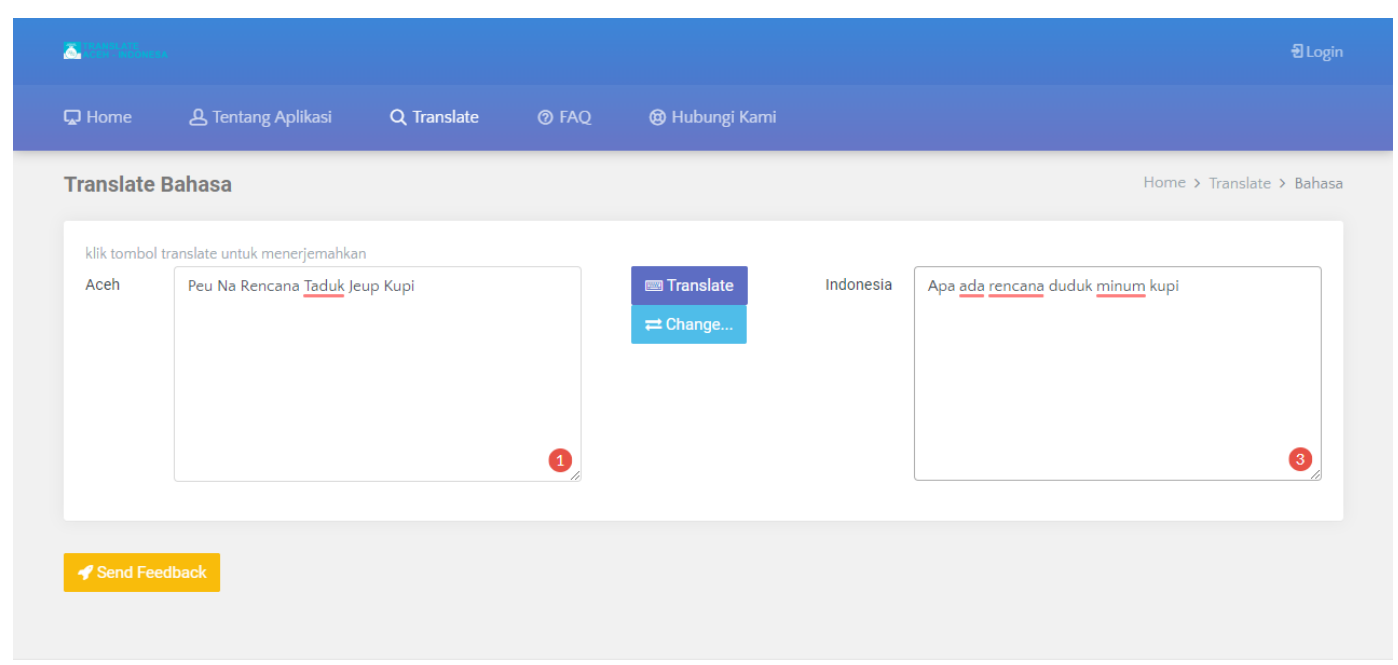

$2019 \odot$ Translate - Rule Based

Fig.11. Translate page

On the translation page it consists of 2 text areas where each function is for the translated target and the translation result, on this page the form can be replaced with Aceh-Indonesian or vice versa Indonesia-Aceh. Any inaccurate translation results, visitors or users of the translation can send messages (feedback) as a reference for later dictionary development

\section{Conclusion}

Based on the results of the analysis and design of the Aceh language translator application, it can be seen that until now it is still being done manually. The author can conclude the following points

a. The design of an Acehnese translator application can provide convenience in carrying out the process of translating the Aceh language into Indonesia and vice versa.

b. The rule-based method is used to anticipate the limited number of words contained in the database, in which words in Indonesian which are similar in Acehnese are made in a certain pattern of rules. The rule-based used in this application is the change rule in the front syllable, back syllable, middle syllable, and their combinations.

c. This translation application is two-way, which can translate from Indonesian or Acehnese input.

d. The application can translate words and sentences both consisting of basic words or affix words that are input directly by the user or in the form of files. 


\section{References}

[1] Noermanzah, Noermanzah. "Bahasa sebagai alat komunikasi, citra pikiran, dan kepribadian." Seminar Nasional Pendidikan Bahasa dan Sastra. 2019.

[2] Devianty, Rina. "Bahasa sebagai cermin kebudayaan." Jurnal tarbiyah 24.2 (2017).

[3] Prasasti, Ratna. "Pengaruh bahasa gaul terhadap penggunaan bahasa Indonesia mahasiswa Unswagati." LOGIKA Jurnal Ilmiah Lemlit Unswagati Cirebon 18.3 (2016): 114-119.

[4] Lestyarini, Beniati. "Penumbuhan semangat kebangsaan untuk memperkuat karakter Indonesia melalui pembelajaran bahasa." Jurnal pendidikan karakter 3 (2012).

[5] Suweta, I. Made. "BAHASA BALI SEBAGAI SENTRAL KEBUDAYAAN BALI." Maha Widya Bhuwana: Jurnal Pendidikan, Agama dan Budaya 2.1 (2019): 7-16.

[6] Hendariningrum, Retno, and Muhammad Edy Susilo. "Fashion dan gaya hidup: identitas dan komunikasi." Jurnal Ilmu Komunikasi 6.1 (2014): 25-32.

[7] Bugiardo, Dian. Berkomunikasi ala Net-Generation. Elex Media Komputindo, 2015.

[8] Rachmawati, Rini. Pengembangan Perkotaan d: alam Era Teknologi Informasi dan Komunikasi. UGM PRESS, 2018.

[9] Caesar, Agil M. "Perancangan Aplikasi Kamus Bahasa Aceh Berbasis Android." (2018).

[10] www.acehplanet.com. Ternyata ada 9 Bahasa Daerah di Aceh. URL: http://acehplanet.com/ternyata-ada-9-bahasa-daerah-diaceh/. Retrieved 23 October 2020 (23:36).

[11] Wali, M. "Modul Praktikum Rekayasa Perangkat Lunak." Ellunar Publisher. (2020).

[12] Ahmad, Lukman. Sistem Informasi Manajemen: Buku Referensi: Sistem Informasi Manajemen. Vol. 1. KITA Publisher. (2018).

[13] Wali, Muhammad, and Lukman Ahmad. "Perancangan Aplikasi Source code library Sebagai Solusi Pembelajaran Pengembangan Perangkat Lunak." Jurnal JTIK (Jurnal Teknologi Informasi dan Komunikasi) 1.1 (2017): 39-47.

[14] Iqbal, Taufiq, Daniel Aprizal, and Muhammad Wali. "Aplikasi Manajemen Persediaan Barang Berbasis Economic Order Quantity (EOQ)." Jurnal JTIK (Jurnal Teknologi Informasi dan Komunikasi) 1.1 (2017): 48-60. 